\title{
Improved germination of the seeds of whistling pine (Casuarina equisetifolia) Forst and Forst (Casuarinaceae) by various presowing treatments
}

\author{
JMO Eze ${ }^{\star}$, MO Ahonsi \\ Department of Botany, University of Benin, Benin City, Nigeria
}

(Recieved 17 May 1993; accepted 28 September 1993)

\begin{abstract}
Summary - Various methods were tried for inducing the seeds of Casuarina equisetifolia Forst and Forst (Casuarinaceae) to germinate faster or in greater numbers than under natural conditions. Percentage germination in untreated seeds (control) ranged from 7 to $16 \%$ over an average of 6 days. Some treatments increased the percentage germination by different values up to $62 \%$. The most effective treatment was application of a $0.1 \mathrm{mM}$ solution of $\mathrm{GA}_{3}$ followed by that of a $2500 \mathrm{mg} \mathrm{dm}^{-3}$ solution of ascorbic acid, and a $10 \mathrm{mM}$ solution of $\mathrm{NaNO}_{3}$. Other effective treatments included scarification with concentrated $\mathrm{H}_{2} \mathrm{SO}_{4}$, and application of $0.1 \mathrm{mM} I A A$ solution. Incubating soaked seeds in continuous red light caused the germination to start earlier and also increased the overall germination. Germination was inhibited under continuous blue light, green light and in the dark. Germination was completely prevented in seeds pretreated with a $0.1 \mathrm{mM}$ solution of $A B A$.
\end{abstract}

\section{Casuarina equisetifolia / germination / $\mathrm{GA}_{3}$}

Résumé - Amélioration de la germination des graines de Casuarina equisetifolia Forst et Forst (Casuarinaceae) par divers traitements avant semis. Divers traitements ont été essayés pour induire les graines de Casuarina equisetifolia à germer plus vite ou en plus grande proportion que dans les conditions naturelles. Le pourcentage de germination des graines non traitées (témoins) variait de 7 à 16\%, en $6 j$ en moyenne. Certains traitements ont amélioré ce pourcentage de valeurs variées, jusqu'à $62 \%$. Le traitement le plus efficace a été l'application d'une solution de $\mathrm{GA}_{3}$ à $0,1 \mathrm{mM}$, suivie de celle d'une solution d'acide ascorbique à $2,5 \mathrm{mg} \mathrm{dm}^{-3}$ et d'une solution à $10 \mathrm{mM}$ de $\mathrm{NaNO}_{3}$. La scarification par $\mathrm{H}_{2} \mathrm{SO}_{4}$ concentré et l'application d'une solution de AlA à $0,1 \mathrm{mM}$ a été également efficace. L'incubation des graines imbibées sous lumière rouge continue entraîna une germination plus précoce, et un pourcentage de germination amélioré. La germination a été inhibée en lumière bleue continue, en lumière verte ou à l'obscurité. La germination a été complètement inhibée par un prétraitement par une solution à $0,1 \mathrm{mM}$ d'AlB.

Casuarina equisetifolia / germination $/ G A_{3}$

\footnotetext{
* Correspondence and reprints: Enugu State University of Science and Technology, Faculty of Applied Natural Sciences, Adada Campus, PO Box 161, Nsukka, Nigeria
} 


\section{INTRODUCTION}

The whistling pine (Casuarina equisetifolia) Forst and Forst (Casuarinaceae) (Syn $C$ litorea $L$ ) is extensively planted as wind breaks to protect crops in agro-forestry. It is also widely used to stabilize coastal sand dunes because of its resistance to salt-laden winds. The wood is resistant to decomposition in soil or salt water, and is often used as round wood for making piles, poles and fences. The bark is used for tanning. However, the uses for which $C$ equisetifolia and its hybrids are most commonly known are as ornamental plants for urban decoration, parks and seaside resorts. It has a high calorific value (ca $5000 \mathrm{kCal} \mathrm{kg}^{-1}$ ) and the wood is therefore an excellent source of fuel wood and charcoal. The young twigs are also used for feeding cattle (Mclean and Ivimey-Cook, 1968; Gerth Van Wijk, 1971; Howes, 1975; Domergues, 1990).

The germination of the seeds of such an economically important tree is of great interest to different groups of plant scientists such as botanists, agro-foresters and silviculturists. This is accentuated as the successful propagation of any Casuarina spp by a vegetative method is very limited even with IBA hormone application (Mahmood and Possuswam, 1980; Turnbull et al, 1986; Pinyopusarerk and Bolan, 1990). There is a paucity of reports of germination studies on the whistling pine and the present study was undertaken to extend what is already known about its germination.

Germination studies have been carried out in the seeds of several tree species. For instance, Bibbey (1948) worked on woody plant seeds; the US Department of Agriculture (1948) studied seed and its development in 444 species of woody plants; Gill and Bamidele (1981) studied the germination of 3 savanna trees of Nigeria; Etejere et al (1982) and Eze and Orole (1987) studied the germination of Parkia clappertoniana and Prosopis africana, respectively. Williams et al (1989) worked on germination and dormancy in Ptilotus exaltatus. Many aspects of the findings from these various studies may apply to the germination of other seeds including $C$ equisetifolia but this will remain a supposition until the techniques and procedures are actually tried on the experimental material.
MATERIALS AND METHODS

\section{Source of seeds and collection method}

To aid the uniformity of the response, ripe green cones (fruits) were plucked from one particular Casuarina tree in a row at the Ugbowo Campus of the University of Benin, Benin City. The cones were dried in the sun inside a beaker to prevent the small, papery, light seeds from being blown away by the wind. The seeds that appeared to be filled were selected while empty-looking and wrinkled seeds were discriminated against since such seeds always failed to germinate in preliminary trials.

\section{Pre-sowing treatments}

Chemical scarification was carried out by steeping the seeds in concentrated $\mathrm{H}_{2} \mathrm{SO}_{4}$ for 5,10 or $20 \mathrm{~min}$ and subsequently washing thoroughly in running tap water for $5 \mathrm{~min}$. Both the acid-scarified seeds and unscarified ones (control) were sown on filter paper moistened with 2, 10 or $50 \mathrm{mM}$ solution of sodium nitrate $\left(\mathrm{NaNO}_{3}\right)$. Seeds were also treated with a $0.1 \mathrm{mM}$ solution of indole-acetic acid (IAA), gibberellic acid $\left(\mathrm{GA}_{3}\right)$ or abscisic acid (ABA). The control and scarified seeds were also soaked in 250, 500, 1000,2500 , 5000 and $10000 \mathrm{mg} \mathrm{dm}^{-3}$ of ascorbic acid for $24 \mathrm{~h}$, after which they were sown on water-moistened filter papers in Petri dishes.

The effect of heating on the germination of control and acid-scarified seeds was monitored by preheating dry seeds in the oven for 2 or $5 \mathrm{~min}$ at temperatures of $40,55,70$ and $90^{\circ} \mathrm{C}$. After the heat treatment the dry seeds were sown on moist filter papers as usual.

The effect of light was also investigated by incubating the control and scarified seeds sown on moist filter papers and exposing them to lighting conditions of alternating day and night, or continuous fluorescent white light. Furthermore, some of the Petri dishes containing the prepared seeds were covered with blue, green, orange or red cellophane filters and placed under continuous white light. These seeds were thus allowed to germinate under the above-mentioned coloured light.

In all experiments 75 seeds were sown in 3 Petri dishes (each containing 25 seeds). A seed was taken to have germinated once the radicle had pushed out from the seed coat. All seeds were sown on filter paper moistened with water or appropriate solution. 


\section{RESULTS}

\section{Acid scarification}

Five minutes was the most effective time of soaking in concentrated $\mathrm{H}_{2} \mathrm{SO}_{4}$ as a scarification treatment to improve the percentage germination (table I). No seed was found to survive $20 \mathrm{~min}$ of soaking in the acid.

\section{Effect of scarification}

The results summarized in tables I-VI show that scarification with concentrated $\mathrm{H}_{2} \mathrm{SO}_{4}$ was a very effective method for improving the germination of $C$ equisetifolia seeds.

\section{Effect of other treatments}

Several other treatments were, however, more effective than acid scarification in the sense that the unscarified seeds given such treatments alone had better germination than the acidscarified seeds. These were soaking with $10 \mathrm{mM}$ $\mathrm{NaNO}_{3}$ solution, (table II), $0.1 \mathrm{mM}$ solution of $\mathrm{GA}_{3}$ (table III) and $2500 \mathrm{mg} \mathrm{dm}^{-3}$ ascorbic acid solution (table IV). In each of these treatments, however, acid scarification pretreatment $(B)$ gave additional enhancement of germination. Other treatments that were also better than the control

Table I. Total number germinating out of 75 seeds, untreated (control) or scarified with concentrated $\mathrm{H}_{2} \mathrm{SO}_{4}$ for various periods of time.

\begin{tabular}{cllcc} 
Time $(d)$ & Untreated & \multicolumn{3}{c}{ Duration (min) of } \\
from sowing & (control) & \multicolumn{3}{c}{ scarification with acid } \\
& & 5 & 10 & 20
\end{tabular}

\begin{tabular}{rrrrr}
\hline 5 & 0 & 0 & 0 & 0 \\
6 & 3 & 6 & 3 & 0 \\
7 & 5 & 10 & 9 & 0 \\
8 & 5 & 11 & 11 & 0 \\
9 & 5 & 13 & 12 & 0 \\
10 & 5 & 14 & 12 & 0 \\
11 & 5 & 15 & 12 & 0 \\
12 & 5 & 15 & 12 & 0 \\
\hline
\end{tabular}

* No germination observed prior to the first day recorded in the table. alone were: soaking with $0.1 \mathrm{mM}$ solution of IAA (table III); heating to 55 or $70^{\circ} \mathrm{C}$ (table V); and continuous red light (table VI). Continuous light on the whole seemed to advance the time of germination by $1 \mathrm{~d}$ in the seed lots tested (table VI). The tests on light effect were repeated 3 times and although the actual results obtained kept varying, the trend was consistent. Germination was drastically reduced in continuous darkness (table $\mathrm{VI}$ ) while complete inhibition was caused by $0.1 \mathrm{mM} \mathrm{ABA}$ (table III).

\section{DISCUSSION}

Primary dormancy has to do with incomplete development of the embryo such that the seed cannot germinate despite satisfactory environmental conditions for germination. After full development the seed may revert to secondary dormancy if external conditions are unfavourable for germination (Wilson and Loomis, 1962). In this context, seed dormancy in Casuarina equisetifolia does not appear to be of the primary or secondary type. This is implied from the observation that the seeds used in this study were harvested fresh from the tree and germination occurred readily once the external conditions for germination were satisfied. However, the germination percentage seems to be inherently low. Each experiment in this study was repeated at least twice and the results presented

Table II. Total number germinating out of 75 control (A) or scarified (B) seeds moistened with different molar concentrations of sodium nitrate $\left(\mathrm{NaNO}_{3}\right)$.

\begin{tabular}{|c|c|c|c|c|c|c|c|c|}
\hline \multirow{2}{*}{$\begin{array}{l}\text { Time (d) } \\
\text { from } \\
\text { sowing* }\end{array}$} & & \multicolumn{7}{|c|}{ Concentration of $\mathrm{NaNO}_{3}(\mathrm{mM})$} \\
\hline & & ontrol) & & 2 & & & & \\
\hline & $A$ & $B$ & $A$ & $B$ & $A$ & $B$ & $A$ & $B$ \\
\hline
\end{tabular}

$\begin{array}{rrrrrrrrr}5 & 0 & 0 & 0 & 0 & 0 & 0 & 0 & 0 \\ 6 & 3 & 8 & 4 & 10 & 1 & 11 & 1 & 5 \\ 7 & 5 & 13 & 13 & 20 & 12 & 23 & 4 & 7 \\ 8 & 5 & 13 & 18 & 24 & 20 & 27 & 7 & 8 \\ 9 & 5 & 13 & 19 & 24 & 22 & 28 & 9 & 8 \\ 10 & 5 & 13 & 19 & 24 & 23 & 28 & 9 & 8 \\ 11 & 5 & 13 & 19 & 24 & 24 & 28 & 9 & 8 \\ 12 & 5 & 13 & 19 & 24 & 24 & 28 & 9 & 8\end{array}$

* No germination observed prior to the first day recorded in the table. 
Table III. Total number germinating out of 75 control (A) or scarified (B) seeds moistened with water or $0.1 \mathrm{mM}$ of the named phytohormone.

\begin{tabular}{|c|c|c|c|c|c|c|c|c|c|c|}
\hline \multirow{2}{*}{$\begin{array}{l}\text { Time }(d) \\
\text { from sowing }\end{array}$} & \multicolumn{2}{|c|}{ Water } & \multicolumn{2}{|c|}{$I A A$} & \multicolumn{2}{|c|}{$G A_{3}$} & \multicolumn{3}{|c|}{$A B A$} & \multirow[b]{2}{*}{$B_{0}^{\star \star}$} \\
\hline & $A$ & $B$ & $A$ & $B$ & $A$ & $B$ & $A$ & $B$ & $A_{0}^{* *}$ & \\
\hline 2 & 0 & 0 & 0 & 0 & 0 & 0 & 0 & 0 & 0 & 0 \\
\hline 3 & 0 & 0 & 0 & 0 & 0 & 0 & 0 & 0 & 1 & 0 \\
\hline 4 & 0 & 0 & 0 & 0 & 0 & 0 & 0 & 0 & 2 & 1 \\
\hline 5 & 0 & 0 & 0 & 0 & 0 & 0 & 0 & 0 & 2 & 1 \\
\hline 6 & 4 & 6 & 9 & 5 & 10 & 17 & 0 & 0 & 2 & 1 \\
\hline 7 & 10 & 9 & 11 & 18 & 26 & 29 & 0 & 0 & 2 & 1 \\
\hline 8 & 10 & 10 & 14 & 19 & 28 & 36 & 0 & 0 & 2 & 1 \\
\hline 9 & 10 & 10 & 14 & 19 & 32 & 37 & 0 & 0 & 2 & 1 \\
\hline 10 & 10 & 10 & 14 & 19 & 36 & 46 & 0 & 0 & 2 & 1 \\
\hline 11 & 10 & 10 & 14 & 19 & 38 & 47 & 0 & 0 & 2 & 1 \\
\hline 12 & 10 & 10 & 14 & 19 & 43 & 47 & 0 & 0 & 2 & 1 \\
\hline 13 & 10 & 10 & 14 & 19 & 43 & 47 & 0 & 0 & 2 & 1 \\
\hline
\end{tabular}

* No germination observed prior to the first day recorded in the table. ** Seeds presoaked in ABA for $6 \mathrm{~d}$ and thoroughly washed with water before sowing.

here are a confirmation of a consistent trend. Waxy and hard seed coat dormancy has been broken with the use of concentrated $\mathrm{H}_{2} \mathrm{SO}_{4}$ by several workers (Mayer and Poljakoff-Mayber, 1963; Ballard, 1973; Gill and Bamidele, 1981; Etejere et al, 1982; Eze and Orole, 1987). The duration of treatment largely depends on the hardness and thickness of the testa. Thus Dialium guineensis required $10 \mathrm{~min}$ (Gill and Bamidele, 1981), Parkia clappertoniana 15 min (Etejere et al, 1982), Brachiara decumbens $20 \mathrm{~min}$
(Whiteman and Mendra, 1982), and Acacia farnesiana 30 min (Gill et al, 1986). In the case of Casuarina equisetifolia in the present study, only 5 min was required, which is not surprising since the seed is very small and its coat is thin. The basis of action by concentrated $\mathrm{H}_{2} \mathrm{SO}_{4}$ or other strong mineral acids has been discussed by Mayer and Poljakoff-Mayber (1963).

Under favourable external conditions the percentage germination of the Casuarina seeds is low (ca 10\%), although some of the seeds may

Table IV. Total number germination out of 75 control (A) or scarified (B) seeds pre-soaked for $24 \mathrm{~h}$ in various concentrations of ascorbic acid.

\begin{tabular}{|c|c|c|c|c|c|c|c|c|c|c|c|c|c|c|}
\hline \multirow{3}{*}{$\begin{array}{l}\text { Time }(d) \\
\text { from sowing* }\end{array}$} & \multicolumn{14}{|c|}{ Ascorbic acid concentrations ( $\mathrm{mg} \mathrm{dm}^{-3}$ ) } \\
\hline & \multicolumn{2}{|c|}{0} & \multicolumn{2}{|c|}{250} & \multicolumn{2}{|c|}{500} & \multicolumn{2}{|c|}{1000} & \multicolumn{2}{|c|}{2500} & \multicolumn{2}{|c|}{5000} & \multicolumn{2}{|c|}{10000} \\
\hline & $A$ & $B$ & $A$ & $B$ & $A$ & $B$ & $A$ & $B$ & $A$ & $B$ & $A$ & $B$ & $A$ & $B$ \\
\hline 4 & 0 & 0 & 0 & 0 & 0 & 0 & 0 & 0 & 0 & 0 & 0 & 0 & 0 & 0 \\
\hline 5 & 1 & 3 & 2 & 3 & 5 & 4 & 4 & 3 & 8 & 5 & 3 & 1 & 5 & 2 \\
\hline 6 & 7 & 6 & 15 & 11 & 14 & 9 & 19 & 7 & 25 & 14 & 13 & 5 & 19 & 8 \\
\hline 7 & 11 & 13 & 17 & 19 & 15 & 21 & 19 & 15 & 29 & 26 & 16 & 14 & 24 & 12 \\
\hline 8 & 11 & 13 & 17 & 19 & 15 & 21 & 19 & 21 & 29 & 31 & 16 & 17 & 24 & 19 \\
\hline 9 & 11 & 13 & 17 & 19 & 16 & 21 & 19 & 21 & 30 & 32 & 16 & 17 & 24 & 19 \\
\hline 10 & 11 & 13 & 17 & 19 & 16 & 21 & 19 & 21 & 30 & 32 & 16 & 17 & 24 & 19 \\
\hline 11 & 11 & 13 & 17 & 19 & 16 & 21 & 19 & 21 & 30 & 32 & 16 & 17 & 24 & 19 \\
\hline 12 & 11 & 13 & 17 & 19 & 16 & 21 & 19 & 21 & 30 & 32 & 16 & 17 & 24 & 19 \\
\hline
\end{tabular}

\footnotetext{
* No germination observed prior to the first day recorded in the table.
} 
Table V. Number of seeds germinating out of 75 contol (A) or scarified (B) seeds pre-heated in the oven for 2 or 5 min at different temperatures.

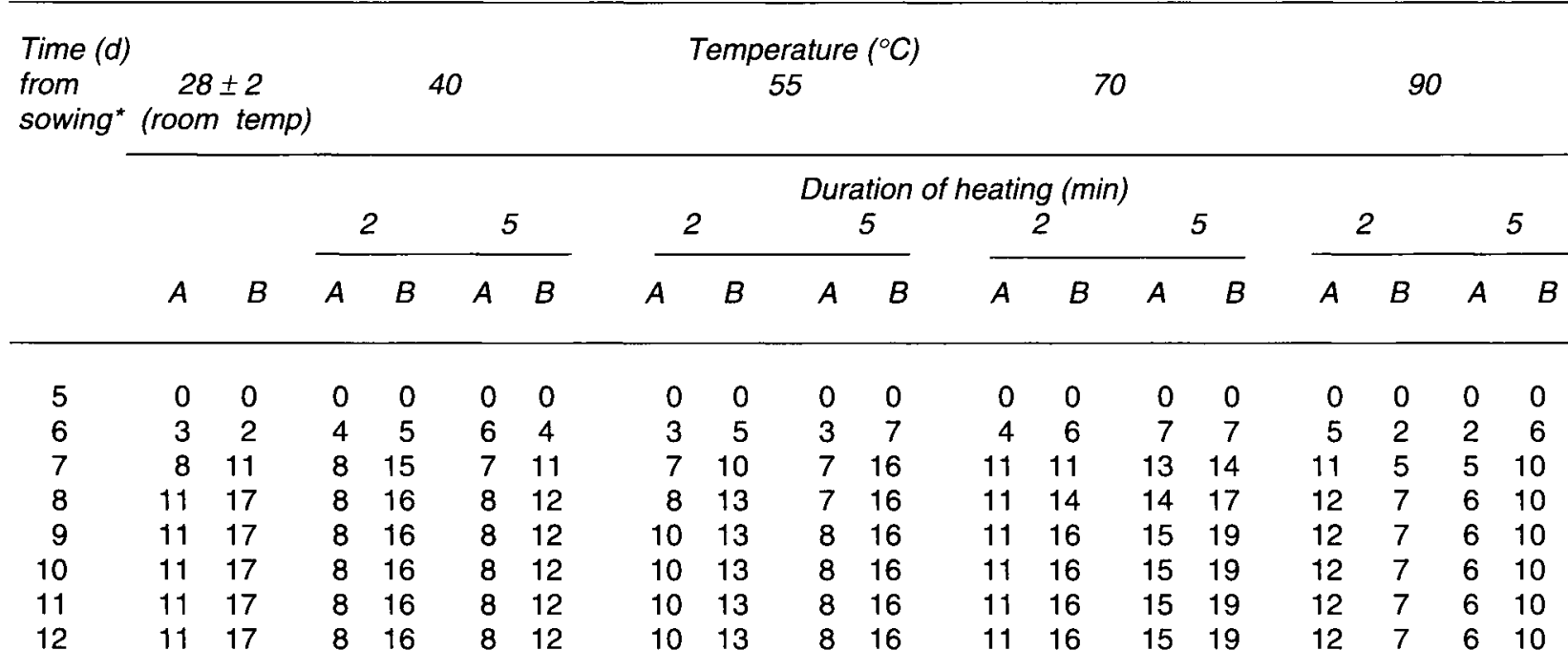

* No germination observed prior to the first day recorded in the table.

germinate readily. Even with overcoming hardcoat dormancy with scarification the germination improves only to about $20 \%$. This suggests that water impermeability due to seed coat hardness may not be the only reason for the low percentage germination. This is supported by the favourable results obtained with chemical treatment in the absence of scarification, eg, the application of IAA, $\mathrm{NaNO}_{3}$, ascorbic acid and particularly $\mathrm{GA}_{3}$. With Prosopis africana Eze and Orole (1987) obtained 40 and $75 \%$ germination, respectively, for the unscarified and scarified seeds treated with $\mathrm{NaNO}_{3}$ compared to $30 \%$ germination in the untreated control. The basis of $\mathrm{NaNO}_{3}$ effectiveness has been discussed by Hendricks and TayIorson (1972). The results of Shineng (1988) working on Sesbania showed a promoting effect on germination when seeds were pretreated by soaking in ascorbic acid solution. The optimum effect was obtained with a concentration of 500 $-1000 \mathrm{mg} \mathrm{dm}^{-3}$, but there was no discussion on the basis of the ascorbic acid effect. In the

Table VI. Total number germination out of 75 control $(A)$ or scarified $(B)$ seeds sown on moist filter paper under different light conditions.

\begin{tabular}{|c|c|c|c|c|c|c|c|c|c|c|c|c|c|c|}
\hline \multirow{3}{*}{$\begin{array}{l}\text { Time (d) } \\
\text { from } \\
\text { sowing }\end{array}$} & \multirow{2}{*}{\multicolumn{2}{|c|}{$\begin{array}{l}\text { Alternating } \\
\text { day and } \\
\text { night }\end{array}$}} & \multirow{2}{*}{\multicolumn{2}{|c|}{ Darkness }} & \multicolumn{10}{|c|}{ Colour of continuous light } \\
\hline & & & & & \multicolumn{2}{|c|}{ White } & \multicolumn{2}{|c|}{ Blue } & \multicolumn{2}{|c|}{ Green } & \multicolumn{2}{|c|}{ Orange } & \multicolumn{2}{|c|}{ Red } \\
\hline & $A$ & $B$ & $A$ & $B$ & $A$ & $B$ & $A$ & $B$ & $A$ & $B$ & $A$ & $B$ & $A$ & $B$ \\
\hline 4 & 0 & 0 & 0 & 0 & 0 & 0 & 0 & 0 & 0 & 0 & 0 & 0 & 0 & 0 \\
\hline 5 & 0 & 0 & 0 & 0 & 2 & 1 & 1 & 2 & 2 & 2 & 2 & 2 & 4 & 3 \\
\hline 6 & 3 & 2 & 0 & 0 & 13 & 8 & 1 & 2 & 2 & 2 & 13 & 7 & 13 & 11 \\
\hline 7 & 8 & 11 & 1 & 2 & 13 & 15 & 1 & 2 & 3 & 2 & 13 & 11 & 13 & 20 \\
\hline 8 & 11 & 17 & 1 & 2 & 13 & 15 & 1 & 2 & 3 & 2 & 13 & 11 & 15 & 20 \\
\hline 9 & 11 & 17 & 1 & 2 & 13 & 15 & 1 & 2 & 3 & 2 & 13 & 11 & 15 & 20 \\
\hline 10 & 11 & 17 & 1 & 2 & 13 & 15 & 1 & 2 & 3 & 2 & 13 & 11 & 15 & 20 \\
\hline 11 & 11 & 17 & 1 & 2 & 13 & 15 & 1 & 2 & 3 & 2 & 13 & 11 & 15 & 20 \\
\hline 12 & 11 & 17 & 1 & 2 & 13 & 15 & 1 & 2 & 3 & 2 & 13 & 11 & 15 & 20 \\
\hline
\end{tabular}

\footnotetext{
* No germination observed prior to the first day recorded in the table.
} 
present study with Casuarina the promoting effect of ascorbic acid was confirmed but the optimum concentration was found at $2500 \mathrm{mg} \mathrm{dm}^{-3}$ It should be noted that ascorbic acid is a strong reducing agent. Since it further enhances the germination of seeds adequately scarified with concentrated $\mathrm{H}_{2} \mathrm{SO}_{4}$, its dormancy-breaking mechanism may be metabolic rather than physical. Conflicting results have been obtained with IAA by other workers but according to Mayer and Poljakoff-Mayber (1963) this depends on the species and IAA concentration used. Baskin and Baskin (1974) and several other workers have reported the stimulating effect of $\mathrm{GA}_{3}$ on seed germination. In the present study this has been the most effective germination promoter, giving up to 57 and $62 \%$, unscarified and scarified seeds, respectively. A well-known effect of this hormone is to break dormancy and promote germination under otherwise unfavourable conditions, eg, germination of light-requiring lettuce seeds in the dark (Baskin and Baskin, 1974). Reynolds and Thompson (1971) showed that the maximum temperature for germination of lettuce seeds could be moved upwards or downwards by treating seeds with kinetin or ABA, respectively. In the present study there was no attempt to investigate the interaction of the effects of $A B A$ and temperature on seed germination. Thus only the inhibitory effect of $A B A$ on germination was confirmed. The usual absence of spontaneous emergence of Casuarina seedlings in the vicinity of fruiting parent trees, unlike a number of other trees, is consistent with the low percentage germination of untreated seeds as found in this study. Another rational explanation would be the papery light weight of the seeds which are easily blown away from around the parent tree.

\section{REFERENCES}

Ballard LA (1973) Physical barriers to germination. Seed Sci Technol 1, 285-295

Baskin JM, Baskin CC (1974) Breaking dormancy in seeds of Isanthus branchiathus (Labiatae) with gibberellic acid. Phyton 32, 159-165

Bibbey RO (1948) Physiological studies on woody plant seed germination. Plant Physiol 23, 467-484

Dommergues $Y$ (1990) Casuarina equisetifolia: an old-timer with a new future. Nitrogen Fixing Tree Association (NFTA) Waimanalo, 90, 1-2
Etejere EO, Fawole MO, Sani A (1982) Studies on the seed germination of Parkia clappertoniana. Turrialba $32,181-185$

Eze JMO, Orole BC (1987) Germination of the seeds of Prosopis africana. Nigerian J Forestry 17, 12-16

Gerth Van Wijk HL (1971) A Dictionary of Plant Names. vol 1 A Asher and Co, Vaals, Amsterdam, pp 267-268

Gill LS, Bamidele JF (1981) Seed morphology, germination and cytology of three savanna trees of Nigeria. Nigerian J Forestry 2, 16-23

Gill LS, Jegede RO, Husaini SWH (1986) Studies on the seed germination of Acacia farnesinai (L) Wild (Legimincsae). J Tree Sci 5, 92-97

Hendricks SB, Taylorson RB (1972) Promotion of seed germination by nitrates and cyanides. Nature 237 (5351), 169-170

Howes FN (1975) A Dictionary of Useful and Everyday Plants and their Common Names. Cambridge Univ Press, London, p 27

Mahmood AM, Possuswam PK (1980) Propagation of Casuarina junghuhniana by planting shoots and root suckers. Indian For 106 (4), 298-299

Mayer AM, Poljakoff-Mayber A (1963) The Germination of Seeds. Pergamon Press. London, pp 31-94

Mclean RC, Ivimey-Cook WR (1968) Textbook of Theoretical Botany, vol 2 (4th edition). Longman, Green \& Co Ltd, London, pp 1765-1767

Pinyopusarerk K, Boland DJ (1990) Casuarina junghuhniana: a highly adaptable tropical causarina. NFT Highlights, 90 (04), 1-2

Reynolds T, Thompson PA (1971) Characterisation of the high temperature inhibition of germination of lettuce (Lactuca sativa). Physiol Plant 24, 544-547

Shineng $H$ (1988) Effect of ascorbic acid pretreatments on germination and early growth of Sesbania sesban (L) Merril. Nitrogen Fixing Tree Research Reports, vol 6, 76-77

Turnbull JW, Martensz PN, Hall N (1986) Notes on lesser-know Australian trees and shrubs with potential for fuelwood and agroforestry. In: Multipurpose trees and shrubs: lesser-known species for fuelwood and agroforestry (JW Turnbull, ed) ACIAR, Canberra, Australia, pp 81-90

USDA (United States Department of Agriculture) (1948) Seed and its development. Woody Plant Seed Manual. Miscellaneous publications 654, $416 \mathrm{pp}$

Whiteman PC, Mendra K (1982) Effect of concentrated sulphuric acid on Brachiaria decumbens seeds. Seed Sci Technol 10, 233-242

Williams RR, Holliday KC, Bennel MR (1989) Cultivation of the pink mulla mulla, Ptilotus exastatus: seed germination and dormancy. Sci Hortic 40, 267-274

Wilson CL, Loomis WE (1962) Botany (3rd edition) Holt, Rinehart and Winston publishers, $573 \mathrm{pp}$ 